\title{
Population Changes in a Community of Alkaliphilic Iron-Reducing Bacteria Due to Changes in the Electron Acceptor: Implications for Bioremediation at Alkaline Cr(VI)-Contaminated Sites
}

\author{
Samuel J. Fuller • Ian T. Burke • \\ Duncan G. G. McMillan • Weixuan Ding • \\ Douglas I. Stewart
}

Received: 6 November 2014 / Accepted: 27 April 2015/Published online: 13 May 2015

(C) The Author(s) 2015. This article is published with open access at Springerlink.com

\begin{abstract}
A serial enrichment culture has been grown in an alkaline Fe(III)-citrate-containing medium from an initial inoculum from a soil layer beneath a chromium ore processing residue (COPR) disposal site where $\mathrm{Cr}(\mathrm{III})$ is accumulating from $\mathrm{Cr}(\mathrm{VI})$ containing leachate. This culture is dominated by two bacterial genera in the order Clostridiales, Tissierella, and an unnamed Clostridium XI subgroup. This paper investigates the growth characteristics of the culture when $\mathrm{Cr}(\mathrm{VI})$ is added to the growth medium and when aquifer sand is substituted for $\mathrm{Fe}(\mathrm{III})$-citrate. The aim is to determine how the availability and chemical form of Fe(III) affects the growth of the bacterial consortium, to determine the impact of
\end{abstract}

Electronic supplementary material The online version of this article (doi:10.1007/s11270-015-2437-z) contains supplementary material, which is available to authorized users.

S. J. Fuller · D. I. Stewart $(\bowtie)$

School of Civil Engineering, University of Leeds, Leeds LS2 9JT, UK

e-mail: d.i.stewart@leeds.ac.uk

I. T. Burke $(\bowtie)$

School of Earth and Environment, University of Leeds, Leeds LS2 9JT, UK

e-mail: i.t.burke@leeds.ac.uk

D. G. G. McMillan

University Hospital Jena, Friedrich-Schiller University,

07743 Jena, Germany

W. Ding

School of Process, Environmental and Materials Engineering, University of Leeds, Leeds LS2 9JT, UK
$\mathrm{Cr}(\mathrm{VI})$ on growth, and thus attempt to understand the factors that are controlling $\mathrm{Cr}(\mathrm{III})$ accumulation beneath the COPR site. The culture can grow fermentatively at $\mathrm{pH}$ 9.2, but growth is stronger when it is associated with $\mathrm{Fe}(\mathrm{III})$ reduction. It can withstand $\mathrm{Cr}(\mathrm{VI})$ in the medium, but growth only occurs once $\mathrm{Cr}(\mathrm{VI})$ is removed from solution. $\mathrm{Cr}(\mathrm{VI})$ reduced the abundance of Tissierella $s p$. in the culture, whereas the Clostridium $X I$ sp. was $\mathrm{Cr}(\mathrm{VI})$ tolerant. In contrast, growth with solid phase $\mathrm{Fe}(\mathrm{III})$-oxyhydroxides (present as coatings on aquifer sand) favoured the Tissierella $C$ sp., possibly because it produces riboflavin as an extracellular electron shuttling compound allowing more efficient electron transfer to solid Fe(III) phases. Thus, it is suggested that bacterially mediated $\mathrm{Cr}(\mathrm{III})$ reduction in the soil beneath the COPR site is dependent on Fe(III) reduction to sustain the bacterial community.

Keywords COPR · Bacteria · Alkaliphile Chromium . Iron $\cdot$ Bioremediation

\section{Introduction}

Many industrial processes produce highly alkaline wastes that are contaminated with toxic trace metals/ metalloids (e.g. coal combustion, lime production, chromium ore processing, cement production, iron and steel manufacture, and bauxite refining to name but a few: Burke et al. 2013; Deakin et al. 2001; Jankowski et al. 2006; Mayes and Younger 2006). Until recently, these 
bulk wastes were often poorly disposed of, frequently in unlined tips (Higgins et al. 1998; Mayes et al. 2008; Stewart et al. 2006). When rainwater infiltrates the waste, it can leach the toxic metals, transporting them into the groundwater beneath disposal sites. The subsequent fate of these toxic metals then depends on the biogeochemical reactions that take place when the alkaline leachate passes through the soil beneath the site.

Microbial $\mathrm{Fe}(\mathrm{III}) / \mathrm{Fe}(\mathrm{II})$ redox cycling can have a major impact on the solubility and mobility of many trace metal/metalloid contaminants in the geosphere, particularly those that form stable oxyanions such as Cr, V, Mo, W, Tc and Se (Lovley 2001). Neo-formed $\mathrm{Fe}(\mathrm{II})$ phases can reduce the oxidation state of some these contaminants (e.g. vanadate, pertechnetate, chromate, selenite; Burke et al. 2006; Charlet et al. 2007; White and Peterson 1996; Whittleston et al. 2011), while others form surface complexes on hydrated Fe(II) minerals (e.g. molybdate, tungstate; O'Loughlin et al. 2010; Rey and Reggiani 2005). As a result, the contaminant is less mobile and, in some cases, less toxic (Veeramani et al. 2011). Bioremediation, by exploiting indigenous iron-reducing soil bacteria, has therefore been suggested as an elegant and relatively inexpensive method to reduce the mobility of these contaminants in the subsurface (Anderson et al. 2003; NABIR 2003).

During dissimilatory Fe(III) reduction, bacteria harvest electrons from organic carbon (the electron donor) and transfer them to the $\mathrm{Fe}$ (III) substrate (the electron acceptor) which is reduced (Liermann et al. 2007). This process generates an electrochemical gradient across the cell membrane (the "proton motive force") which can be used to drive internal processes such as substrate import and ATP synthesis (Kim and Gadd 2008; Madigan et al. 2003; McMillan et al. 2009; Mitchell 1961). Bacteria use several different mechanisms to reduce $\mathrm{Fe}(\mathrm{III})$. These include intracellular reduction of soluble Fe(III) (Glasauer et al. 2007), reduction by surface contact with extracellular Fe(III) (Bae and Lee 2013; Lovley 2008; Shi et al. 2006; White et al. 2013), and extracellular reduction of Fe(III). Extracellular reduction requires a mechanism for transferring electrons between the cells to the iron source. This can involve cells excreting of electron shuttling compounds, such as quinones and flavins (Bae and Lee 2013; Okamoto et al. 2014; von Canstein et al. 2008), opportunistic use of soluble humic substances (Lovley et al. 1998), or the use of conductive appendages that extend from the cell walls (so called 'nanowires'; Gorby et al. 2006).
Some trace metals, including $\mathrm{Cr}(\mathrm{VI}), \mathrm{Tc}(\mathrm{VII}), \mathrm{V}(\mathrm{V})$, $\mathrm{Mo}(\mathrm{VI})$ and $\mathrm{U}(\mathrm{VI})$, can be reduced directly as part of microbial metabolism (Abdelouas et al. 1998; Burke et al. 2006; Carpentier et al. 2005; Harish et al. 2012; Lloyd et al. 2000; Lovley 1993; Shukor et al. 2010). However, there is much debate about whether these compounds can support life as the sole electron acceptors for dissimilatory metabolism. For example, it is relatively common for bacteria to enzymatically reduce $\mathrm{Cr}(\mathrm{VI})$ in both aerobic and anaerobic conditions (Enterobacter cloacae; Harish et al. 2012; Shewanella putrefaciens and Shewanella alga; Liu et al. 2002; Pyrobaculum islandicum; Lloyd and Lovley 2001; Desulfovibrio vulgaris; Lovley and Phillips 1994; e.g. Escherichia coli; Shen and Wang 1993). However, very few bacteria strains are able to use $\mathrm{Cr}(\mathrm{VI})$ as the sole electron acceptor on which to respire, as it can pass through the cell membrane via the sulphate transport system, and it is toxic to many bacteria (Daulton et al. 2007). Once inside the cell wall, it can readily react with DNA and other intercellular agents that are subsequently damaged (Cervantes and Silver 1992; Dhal et al. 2013; Wang and Shen 1997). This suggests the possibility that, although some bacteria can reduce $\mathrm{Cr}(\mathrm{VI})$, the act of reduction can damage the cell leading to mutations and cell death.

Some bacterial species have been isolated from alkaline soils and sediments that can respire using acetate as an electron donor and $\mathrm{Fe}(\mathrm{III})$ as an electron acceptor when the $\mathrm{pH}>9$ (Roh et al. 2007; Zavarzina et al. 2006). However, high $\mathrm{pH}$ is a challenging environment for dissimilatory metal-reducing bacteria as it is difficult to maintain a proton motive force across the cell membrane when the external $\mathrm{pH}$ exceeds that of the cytoplasm. This may favour fermentative metabolism over respiration in highly alkaline conditions. Fermentative bacteria do not need to generate a proton motive force to drive cellular processes. Instead, they can harvest energy from an internally balanced process in which a fermentable organic substrate is both oxidised and reduced (Madigan et al. 2003; Schmitz et al. 2006). ATP is synthesised in the cytoplasm by substrate-level phosphorylation (Barker 1981; Nelson and Cox 2013). Redox balance must be maintained (which places constraints on the amount of energy that can be obtained), and $\mathrm{H}_{2}$ production is one means of disposing of excess electrons (Gottschalk 1986; Kim and Gadd 2008). Some fermentative alkaliphiles in the order Clostridiales have been demonstrated to indirectly reduce extracellular iron by 
dumping electrons to $\mathrm{Fe}(\mathrm{III})$ as an alternative method of maintaining internal redox balance within cells (Dobbin et al. 1999; Garnova et al. 2003; Gorlenko et al. 2004; Kevbrin et al. 1998).

Recently, soil samples were recovered from directly below a nineteenth century COPR disposal site in West Yorkshire. Due to a perched water table in the COPR, water that has a $\mathrm{pH}$ value $>12$ and contains approximately $1 \mathrm{mmol} \mathrm{L}^{-1} \mathrm{Cr}(\mathrm{VI})$ was seeping downwards into these soils (Whittleston et al. 2011; Fuller et al. 2014). However, geochemical analysis showed that there was rapid attenuation of $\mathrm{Cr}(\mathrm{VI})$ with distance from the waste tip and accumulation of $\mathrm{Cr}$ (III) within the organic rich former topsoil layer immediately beneath the tip (Whittleston 2011). Within this soil layer, a large proportion of the $0.5 \mathrm{~N} \mathrm{HCl}$ extractable $\mathrm{Fe}$ (a proxy for microbially available Fe; Weber et al. 2001) was in the $\mathrm{Fe}(\mathrm{II})$ oxidation state. The persistence of the Fe(II) oxidation state in the presence of a $\mathrm{Cr}(\mathrm{VI})$ flux suggests that microbial iron reduction was occurring (Stewart et al. 2010). X-ray absorption spectroscopy analysis of soil samples indicated that $\mathrm{Cr}$ is present as a mixed $\mathrm{Cr}(\mathrm{III})-\mathrm{Fe}(\mathrm{III})$ oxyhydroxide phase, suggesting that the elevated soil $\mathrm{Cr}$ content is due to reductive precipitation of $\mathrm{Cr}$ (VI) by $\mathrm{Fe}(\mathrm{II})$ (Whittleston et al. 2011). Bacteria cultivated from this soil horizon have been repeatedly grown in alkaline anaerobic medium containing yeast extract and $\mathrm{Fe}(\mathrm{III})$ citrate. Growth of the community resulted in the release of riboflavin to the medium, most probably to mediate extracellular electron transfer, and the accumulation of $\mathrm{Fe}(\mathrm{II})$-containing phases in spent medium (Fuller et al. 2014).

Previous work has therefore shown that the fate of toxic $\mathrm{Cr}(\mathrm{VI})$ released from alkaline COPR depends on the biogeochemical reactions that take place when the leachate interacts with soils at the site and particularly on microbial $\mathrm{Fe}(\mathrm{III}) / \mathrm{Fe}(\mathrm{II})$ redox cycling. This paper takes the community of bacteria recovered by Whittleston from soil beneath COPR disposal site and investigates $\mathrm{Cr}(\mathrm{VI})$ reduction in an alkaline anaerobic medium containing $\mathrm{Cr}(\mathrm{VI})$ and $\mathrm{Fe}(\mathrm{III})$ as electron acceptors, with aquifer sand as a source of solid phase $\mathrm{Fe}(\mathrm{III})$ and with $\mathrm{Cr}(\mathrm{VI})$ as the major electron acceptor. The specific objectives are to determine how the availability and chemical form of Fe(III) affect the growth and community structure of the bacterial consortium and determine the impact of an increasing concentration of $\mathrm{Cr}(\mathrm{VI})$ on these properties. Understanding how $\mathrm{Fe}(\mathrm{III})$ and $\mathrm{Cr}(\mathrm{VI})$ reduction processes can be coupled in
COPR-contaminated soils will be discussed with regard to potential bioremediation strategies at such sites.

\section{Materials and Methods}

\subsection{Alkaliphilic Fe(III)-Reducing Bacterial Community}

The bacterial community that was used as an inoculum for experiments reported in this study was originally recovered from the former topsoil horizon immediately beneath a nineteenth century COPR tip (see Whittleston 2011; Whittleston et al. 2011; for details). Since its recovery, the bacteria community used in this study has been repeatedly grown anaerobically in alkaline growth medium containing aqueous $\mathrm{Fe}(\mathrm{III})$ ("Fe(III)citrate medium": details given below). Previous studies have shown that the population of this continuously transferred enrichment culture is stable and contains bacteria of the genera Tissierella, Alkaliphilus and the Clostridium XI subgroup containing Colletotrichum mangenotii, which could be further classified into five operational taxonomic units (OTUs), from now on referred to as Tissierella A (7 \% of the population), Tissierella B (5\%), Tissierella C (36\%), Alkaliphilus (8\%) and Clostridium XI (44\%) (GenBank numbers KF362050-KF362117; Fuller et al. 2014).

\subsection{Alkaline Growth Media}

The basal medium used throughout this study was a semi-defined growth medium that contained $\mathrm{NaH}_{2} \mathrm{PO}_{4} \cdot \mathrm{H}_{2} \mathrm{O}\left(0.356 \mathrm{~g} \mathrm{~L}^{-1}\right), \mathrm{KCl}\left(0.1 \mathrm{~g} \mathrm{~L}^{-1}\right)$, $10 \mathrm{~mL} \mathrm{~L}^{-1}$ each of standard vitamin and mineral mixtures (Bruce et al. 1999), and yeast extract $\left(2 \mathrm{~g} \mathrm{~L}^{-1}\right)$ as a source of energy and carbon. Fe(III)-citrate medium was made by adding $\mathrm{Fe}(\mathrm{III})$ citrate $\left(2 \mathrm{~g} \mathrm{~L}^{-1}\right)$ to the basal medium as a terminal electron acceptor. The $\mathrm{pH}$ value of the medium was buffered to 9.2 by the addition of $\mathrm{Na}_{2} \mathrm{CO}_{3}$ (1 $\mathrm{M}$ carbonate solution). The medium was boiled for $30 \mathrm{~min}$ and then purged with nitrogen for $30 \mathrm{~min}$ to exclude oxygen. One hundred millilitre aliquots of medium were placed in $100-\mathrm{mL}$ glass serum bottles, and the remaining headspaces were filled with $\mathrm{N}_{2}$. The bottles were sealed with butyl rubber stoppers with aluminium crimps, and heat sterilised at $120^{\circ} \mathrm{C}$ for $20 \mathrm{~min} . \mathrm{Fe}$ in the Fe(III)-citrate medium remained soluble as a red-coloured Fe(III)-citrate complex, but the medium also contained a small amount of a hydrous 
ferric oxyhydroxide precipitate which formed when the $\mathrm{pH}$ was adjusted to $\mathrm{pH}$ 9.2.

$\mathrm{Cr}(\mathrm{VI})$ medium was prepared using the same protocol as $\mathrm{Fe}(\mathrm{III})$-citrate medium except that the $\mathrm{Fe}$ (III)citrate was omitted and $\mathrm{K}_{2} \mathrm{CrO}_{4}\left(39 \mathrm{mg} \mathrm{L}^{-1}\right.$; $200 \mu \mathrm{mol} \mathrm{L}^{-1}$ ) was added to the basal medium as an electron acceptor. Similarly, FeCr medium was made by adding both $\mathrm{Fe}(\mathrm{III})$ citrate $\left(2 \mathrm{~g} \mathrm{~L}^{-1}\right)$ and $\mathrm{Cr}(\mathrm{VI})$ to the basal medium. The amount of $\mathrm{K}_{2} \mathrm{CrO}_{4}$ used varied between 100 and $8500 \mu \mathrm{mol} \mathrm{L}^{-1}$ (from 19.5 to $1657.5 \mathrm{mg} \mathrm{L}^{-1}$ ). Henceforth, the amount of $\mathrm{K}_{2} \mathrm{CrO}_{4}$ $\left(\mu \mathrm{mol} \mathrm{L} \mathrm{L}^{-1}\right.$ ) will be indicated by the number included in the medium name (e.g. FeCr200 contained $200 \mu \mathrm{mol} \mathrm{L}{ }^{-1}$ of $\mathrm{Cr}(\mathrm{VI})$.

Aquifer sand medium was prepared by adding alluvial sand to the basal medium (final concentration $100 \mathrm{~g} \mathrm{~L}^{-1}$ ). This sand was recovered from beneath the nineteenth century COPR waste tip (Stewart et al. 2010). It is orange in colour, uniformly granular and was sieved, so only particles less than $0.5 \mathrm{~mm}$ were used. X-ray diffraction (XRD) analysis of the sand indicated it to be predominantly quartz with a little kaolinite. It contained $5 \% \mathrm{Fe}$ and $0.5 \% \mathrm{Mn}$ as determined by X-ray fluorescence (XRF). This solid-phase $\mathrm{Fe}(\mathrm{III})$ is present as fine particles and grain coatings.

Growth of the bacterial community in the absence of $\mathrm{Fe}(\mathrm{III})$ was investigated using the basal medium, and the basal medium supplemented with tri-sodium citrate $\left(2 \mathrm{~g} \mathrm{~L}^{-1}\right)$.

\subsection{Growth Characterisation}

Growth medium bottles were inoculated with $1 \%$ medium containing bacteria in the upper exponential phase of growth (the inoculum typically contained $\sim 200$ cells $\mathrm{nL}^{-1}$ ). Bottles were kept at a constant temperature of $21 \pm 1{ }^{\circ} \mathrm{C}$. The bottles were shaken by hand and sampled $(2 \mathrm{~mL})$ using sterile 19 gauge needles and aseptic, anaerobic technique (Burke et al. 2006). Cell numbers in growth media samples were determined by direct counting using an improved Neubauer haemocytometer viewed under an Olympus BH-2 optical microscope. HCl-extractable Fe(II) was determined by adding $0.5 \mathrm{~mL}$ of sample to $2 \mathrm{~mL}$ of $0.5 \mathrm{~N} \mathrm{HCl}$. One hundred micorlitres was then placed in a disposable 1.5-mL cuvette and mixed with $900 \mu \mathrm{L} \mathrm{diH}_{2} \mathrm{O}$ and $100-\mu \mathrm{L}$ ferrozine solution (Lovley and Phillips 1986). This was then mixed by inversion, the colour allowed to develop for $10 \mathrm{~min}$, and the absorbance at $562 \mathrm{~nm}$ read using a Thermo Scientific BioMate 3 UV/VIS Spectrophotometer. Aqueous $\mathrm{Cr}(\mathrm{VI})$ concentration was measured by first mixing $100-\mu \mathrm{L}$ centrifuged sample, $900 \mu \mathrm{L}$ of $10 \mathrm{mmol} \mathrm{L}^{-1} \mathrm{H}_{2} \mathrm{SO}_{4}$ and $100 \mu \mathrm{L}$ diphenylcarbazide solution in a disposable $1.5-\mathrm{mL}$ cuvette by inversion (USEPA 1992). The colour was left to develop for $10 \mathrm{~min}$ and the absorbance measured at $540 \mathrm{~nm}$. A Hach HQ40d pH meter was used to measure $\mathrm{pH}$.

\subsection{S rRNA Gene Sequencing}

The procedures used to extract bacterial DNA and to sequence the 16S rRNA gene have been reported previously (Fuller 2013). Briefly, DNA was recovered from the growth medium bottles using a FastDNA spin kit for soils (MP Biomedicals, USA). The bottles were shaken, and $15 \mathrm{~mL}$ of suspension was extracted using aseptic technique. Samples were centrifuged at $1800 \times g$ for $15 \mathrm{~min}$, the supernatant removed and the pellet suspended in $978-\mu \mathrm{L}$ sodium phosphate buffer as supplied with the FastDNA kit (the kit manufacturer's protocol was then followed). The eluted DNA was analysed on a $1 \% w / v$ agarose/TBE gel containing ethidium bromide, and the area containing DNA fragments between 3000 and 20,000 bp in length was recovered. The DNA was extracted from the gel using a QIAquick gel extraction kit (QIAGEN 1td, Germany).

Polymerase chain reaction (PCR) was used to amplify a $1.5-\mathrm{kb}$ fragment of the $16 \mathrm{~s}$ rRNA gene using the broad specificity primers $8 \mathrm{f}$ (AGAGTTTGATCCTGGC TCAG) (Eden et al. 1991) and 1492r (ACGGYTACCT TGTTACGA, where $Y=C$ or $T$ ) (Weisburg et al. 1991) or 1525r (AAGGAGGTGWTCCARCC) (Lane 1991). The PCR products were viewed using an agarose/TBE gel, and the desired product was excised and extracted from the gel. This was then ligated into the pGEM-T easy (Promega Corp., USA) cloning vector and transformed into XL1-blue competent $E$. coli cells (Agilent Technologies UK Ltd). The cells were grown on LBagar plates containing $100 \mu \mathrm{g} \mathrm{mL}^{-1}$ ampicillin. Blue/ white colour screening was employed to select viable colonies which were subsequently sent to GATC Biotech Ltd (Germany) for sequencing.

Sequences were checked for chimeras using Mallard (v1.02) (Ashelford et al. 2006), and non-chimeric sequences were grouped into operational taxonomic units (OTUs) using MOTHUR (v1.30.2) ( $>98 \%$ nearest neighbour sequence similarity cut-off) (Schloss et al. 
2009). Sequences from each sample were grouped into OTUs separately before a study-wide analysis was conducted to compare OTUs between samples. Sequences were classified using the Ribosomal Database Project (RDP) naïve Bayesian Classifier using an $80 \%$ bootstrap cut-off value (Wang et al. 2007). This bootstrap cut-off value results in $98.7 \%$ of sequences being correctly classified to genus level (Claesson et al. 2009). All sequences were submitted to the GenBank database with accession numbers KF797922KF798171.

\subsection{Isolation and Quantification of Soluble Electron-Shuttling Compounds}

This was conducted in a similar method to that described in Fuller et al. (2014) and McMillan et al. (2010). One hundred millilitres of early stationary phase culture suspension was centrifuged at $9000 \times g$ for 15 min to separate cells from the growth medium. Culture supernatant was neutralised with HPLC-grade $\mathrm{HCl}$ to $\mathrm{pH} 7$ and extracted with $100 \mathrm{~mL}$ of ethyl acetate. The bottom aqueous layer was discarded. The pooled organic phase was transferred into an acid-cleaned high-density polyethylene (HDPE) bottle, and residual water was removed by drying over sodium sulphate $(5 \mathrm{~g})$ at $4{ }^{\circ} \mathrm{C}$ overnight. The organic phase was then filtered through $0.45-\mu \mathrm{m}$ polytetrafluoroethylene (PTFE) syringe filter (Sartorius) and desiccated using a rotary evaporator. The resulting residue was dissolved with MilliQ $\mathrm{H}_{2} \mathrm{O}$ in an ultrasonic bath (Elma, Elmasonic S30).

A $10-\mathrm{mL}$ column containing 8-g XAD-16 resin (Sigma) was pre-cleaned with $100 \%$ methanol and rinsed thoroughly with deionised $\mathrm{H}_{2} \mathrm{O}$. The ethyl acetate soluble fraction extract was slowly transferred onto the column (XAD-16 is a non-ionic macroreticular resin that is designed to adsorb organic substances up to 40,000 MW from aqueous systems and polar solvents by hydrophobic and polar interactions). Compounds that bound to the resin were eluted sequentially with four bed volumes of 10, 50 and $100 \%$ methanol (HPLC grade Merck). The 50 and $100 \%$ elutions were pooled and reduced to $\sim 10 \mathrm{~mL}$ using a rotary evaporator at $<30{ }^{\circ} \mathrm{C}$. This solution was then transferred to a $15-\mathrm{mL}$ test tube and desiccated by speedvac (Savant SC210A). The resulting dark orange residue was suspended in either $20 \mathrm{mmol} \mathrm{L}{ }^{-1} 3$-( $N$-morpholino) propanesulfonic acid (MOPS), $30 \mathrm{mmol} \mathrm{L}^{-1} \mathrm{Na}_{2} \mathrm{SO}_{4} \mathrm{pH} 7.4$ or deionised $\mathrm{H}_{2} \mathrm{O}$ for further spectroscopy and quantification.
Unused Fe(III)-citrate medium was subjected to the same extraction and used as a control. Flavin quantification was performed by scanning wavelengths from 300 to $700 \mathrm{~nm}$ using a UV-2 UV/Vis spectrophotometer (Unicam). A standard curve was generated by observing known concentrations $(0.05,0.125,0.25,0.5$, $\left.1 \mu \mathrm{mol} \mathrm{L}{ }^{-1}\right)$ of riboflavin. An extinction coefficient at $455 \mathrm{~nm}\left(\varepsilon=12,500 \mathrm{~cm}^{-1} \mathrm{M}^{-1}\right)$ was used to quantify concentration (Otto et al. 1981).

Fluorescence spectra of purified culture supernatant were measured on a Quanta Master 30 (PTI/Photomed) fluorescence spectrometer using a 1-cm path length. Slit widths of 0.5 and $1.5 \mathrm{~mm}$ were used for excitation and emission wavelengths, respectively.

\section{Results}

\subsection{Bacterial Growth in Fe(III)-Citrate Medium}

Growth of the alkaliphilic iron-reducing enrichment culture in $\mathrm{Fe}(\mathrm{III})$-citrate medium started shortly after transfer of the inoculum into fresh medium, with very little time lag (Fig. 1). Cell numbers increased exponentially to a maximum of just over 100 cells $\mathrm{nL}^{-1}$ at $\sim 100 \mathrm{~h}$, when the cell numbers reached the stationary phase (standard sigmoidal growth curves are fitted to the data: Zwietering et al. 1990). The total Fe(II) concentration in the growth bottles showed a very similar sigmoidal trend, but the reduction of $\mathrm{Fe}$ (III) to $\mathrm{Fe}$ (II) lagged behind the increase in cell numbers and was most rapid as cell numbers peaked. Iron reduction was accompanied by a reduction in $\mathrm{pH}$ from 9.1 to $\sim 8.5$. These growth characteristics are substantively the same as those reported by Fuller et al. (2014), although they observed a slightly longer lag phase before the initial growth in cell numbers.

When the bacterial community was grown in the basal medium and the basal medium supplemented with sodium citrate $\left(2 \mathrm{~g} \mathrm{~L}^{-1}\right)$, there were similar short lag phases followed by growth in cell numbers (Fig. 2). However, when the stationary phase was reached, cell numbers in these media without Fe(III) were one third the number in the Fe(III)-citrate medium at the same growth stage (a linear scale has been used in Fig. 2 for cell numbers for ease of comparison). Final cell numbers were slightly higher in the basal medium than in the medium supplemented with sodium citrate, indicating that it is the $\mathrm{Fe}(\mathrm{III})$ and not the citrate that has a 


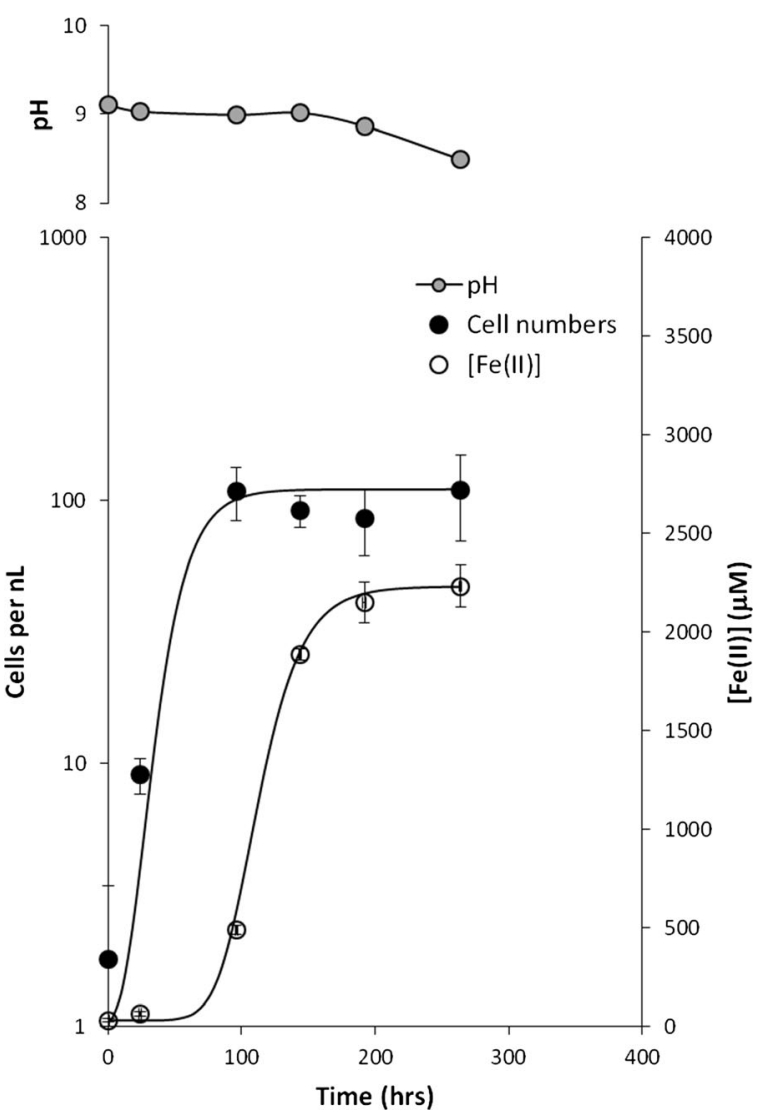

Fig. 1 Growth of alkaliphilic Fe(III)-reducing community in $\mathrm{Fe}$ (III)-citrate medium. Error bars indicate one standard deviation from the mean of triplicate results. Sigmoidal growth curves have been fitted to the cell count and Fe(II) data (Zwietering et al. 1990)

beneficial effect on the growth characteristics of the bacterial community.

\subsection{Bacterial Growth and Metal Reduction in Media Containing Both $\mathrm{Fe}(\mathrm{III})$ and $\mathrm{Cr}(\mathrm{VI})$}

Bacteria in the late exponential phase of growth were taken from $\mathrm{Fe}(\mathrm{III})$-citrate medium and inoculated into $\mathrm{FeCr}$ medium. When the initial $\mathrm{Cr}(\mathrm{VI})$ concentration in the FeCr medium was between 100 and $2000 \mu \mathrm{mol} \mathrm{L}{ }^{-1}$, $\mathrm{Cr}(\mathrm{VI})$ was removed from the aqueous phase of the medium. This started after $\sim 500 \mathrm{~h}$, but the time taken for complete $\mathrm{Cr}(\mathrm{VI})$ removal increased with the initial $\mathrm{Cr}(\mathrm{VI})$ concentration, taking from 100 to $1000 \mathrm{~h}$ (Fig. 3a, Supplementary Information Fig. S1A). The removal of $\mathrm{Cr}(\mathrm{VI})$ from solution was followed by an increased Fe(II) concentration (Fig. 3c, S1C). Thus, the time taken before $\mathrm{Fe}(\mathrm{II})$ production commenced increased with increasing initial $\mathrm{Cr}(\mathrm{VI})$ concentration. In

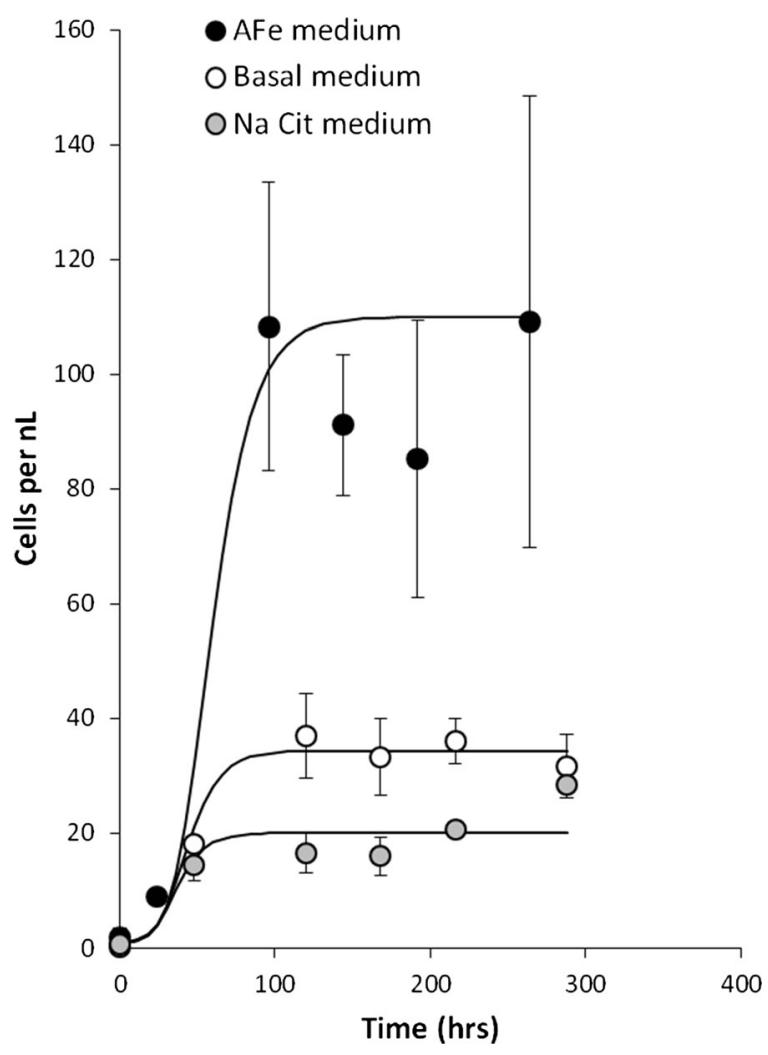

Fig. 2 Growth of alkaliphilic Fe(III)-reducing community in basal, sodium citrate and $\mathrm{Fe}(\mathrm{III})$-citrate media. Error bars indicate one standard deviation from the mean of triplicate results

all these tests, an increase in cell numbers was closely linked to the start of $\mathrm{Fe}(\mathrm{II})$ production.

When the initial $\mathrm{Cr}(\mathrm{VI})$ concentration in the $\mathrm{FeCr}$ medium was 4500 and $8500 \mu \mathrm{mol} \mathrm{L}{ }^{-1} \mathrm{Cr}(\mathrm{VI})$ removal from solution started after 720 and $1224 \mathrm{~h}$, respectively. After $1500 \mathrm{~h}$, the $\mathrm{Cr}(\mathrm{VI})$ concentrations were 2800 and $7500 \mu \mathrm{mol} \mathrm{L}^{-1}$. In these experiments, an increase in cell numbers commenced after $\sim 1000 \mathrm{~h}$, before all the $\mathrm{Cr}(\mathrm{VI})$ was removed from solution and before any $\mathrm{Fe}(\mathrm{II})$ was produced (Fig. 3d, S1D).

In all the tests, the $\mathrm{pH}$ value of the $\mathrm{FeCr}$ medium remained fairly constant at 9.2 for $\sim 400 \mathrm{~h}$ before decreasing slightly to an average final $\mathrm{pH}$ value of 8.5 after 1500 h (Fig. 3b, S1B).

\subsection{Bacterial Growth in Cr(VI) Medium}

Bacteria in the late exponential phase of growth were taken from $\mathrm{Fe}(\mathrm{III})$-citrate medium and grown repeatedly in $\mathrm{Cr}(\mathrm{VI})$ medium (this contained $200 \mu \mathrm{mol} \mathrm{L}{ }^{-1}$ $\mathrm{Cr}(\mathrm{VI})$ ). Colour change of the medium from yellow to 

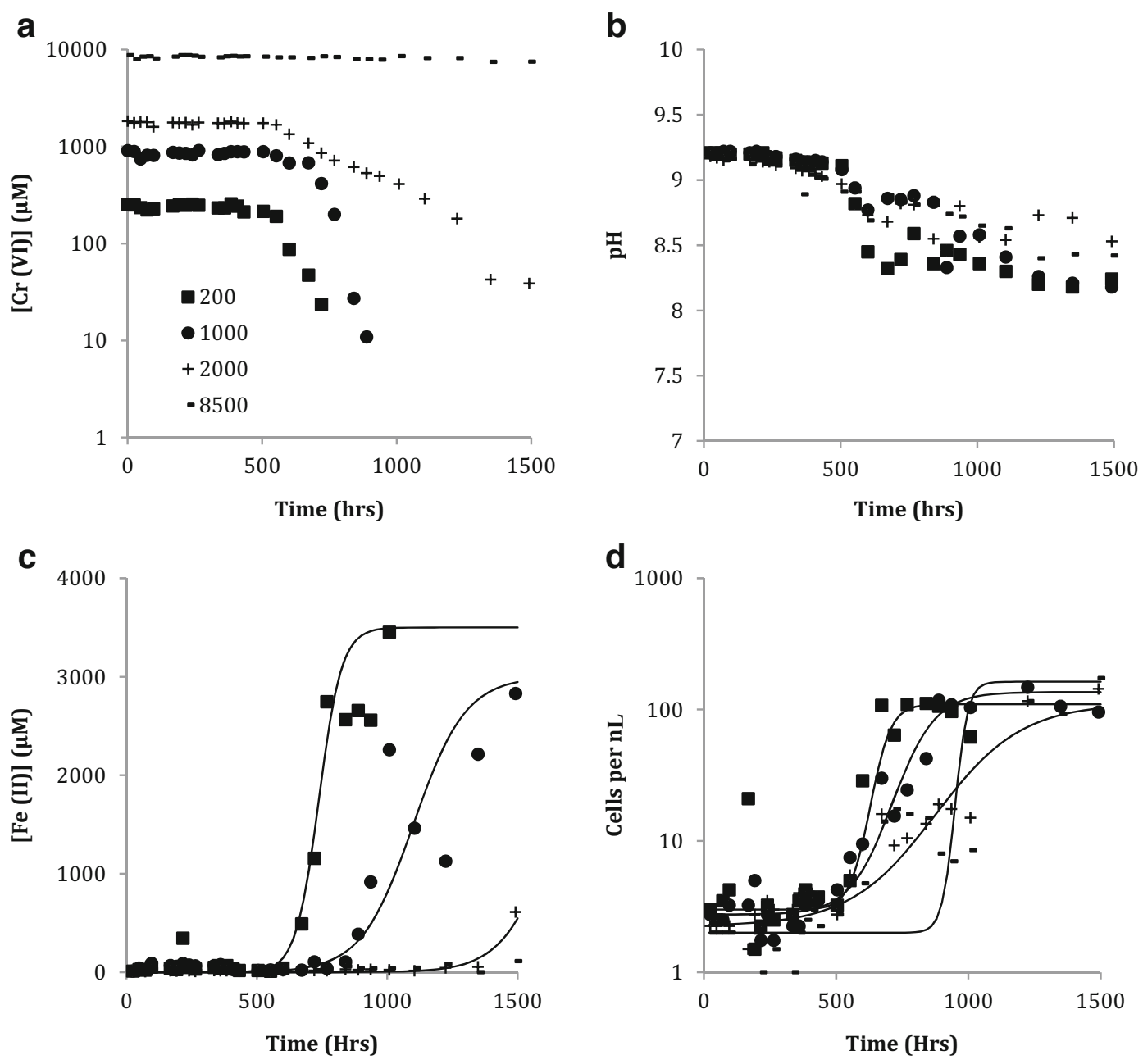

Fig. 3 Growth of alkaliphilic Fe(III)-reducing community in $\mathrm{FeCr}$ medium with initial $\mathrm{Cr}$ (VI) concentrations of 200, 1000, 2000 and $8500 \mu \mathrm{mol} \mathrm{L}{ }^{-1}$. a $\mathrm{Cr}(\mathrm{VI})$ concentration with time. b Total Fe(II) concentration with time. $\mathbf{c}$ Cell numbers with time. $\mathbf{d} \mathrm{pH}$ with time.

clear indicated that $\mathrm{Cr}(\mathrm{VI})$ removal from the aqueous was occurring (spectroscopic measurements on the cleared medium from selected bottles confirmed that $\left.\mathrm{Cr}(\mathrm{VI})<20 \mu \mathrm{mol} \mathrm{L}{ }^{-1}\right)$. The bacterial community was able to sustain weak growth accompanied by $\mathrm{Cr}(\mathrm{VI})$ reduction for 10 repeat subculture cycles before $\mathrm{Cr}(\mathrm{VI})$ removal ceased (see Table 1 for success rates). In growth positive tests, the time taken for complete $\mathrm{Cr}(\mathrm{VI})$ removal from the aqueous phase was about 25 days. Once growth of subsequent subcultures failed, an aliquot of medium from the seventh growth cycle was inoculated back into $\mathrm{Fe}(\mathrm{III})$-citrate medium and grown-on repeatedly. Sustained growth in $\mathrm{Fe}(\mathrm{III})$-citrate medium was observed; however, 16S rRNA gene sequencing

Sigmoidal growth curves have been fitted to the variation cell numbers and $\mathrm{Fe}$ (II) concentration with time (Zwietering et al. 1990)

(reported below) showed that repeated growth in $\mathrm{Cr}(\mathrm{VI})$ medium had applied a selective pressure to the community. Therefore, the revived bacterial community will be referred to as the $\mathrm{Cr}(\mathrm{VI})$ medium community.

\subsection{Bacterial Growth in Aquifer Sand Medium}

The alkaliphilic Fe(III)-reducing community and the $\mathrm{Cr}(\mathrm{VI})$ medium community were inoculated into aquifer sand medium (this medium contained $\mathrm{Fe}$ in the coatings on sand grains and as fine particles). Initially, the amount of $\mathrm{Fe}(\mathrm{II})$ present was very low because the $\mathrm{Fe}$ in the aquifer sand was predominantly in the $\mathrm{Fe}$ (III) oxidation state (Fig. 4). In both systems, there was an 
Table 1 Record of growth of bacterial community in $\mathrm{Cr}(\mathrm{VI})$ medium

\begin{tabular}{lrrrrrrrrrr}
\hline Growth Cycle & 1 & 2 & 3 & 4 & 5 & 6 & 7 & 8 & 9 \\
Outcome & +++ & ++ & +- & ++- & +- & +- & +- & ++- & ++- & - \\
\hline
\end{tabular}

+ denotes final aqueous $\mathrm{Cr}(\mathrm{VI})$ concentration $<10 \%$ of the initial concentration, - indicates no change in the aqueous $\mathrm{Cr}$ (VI) concentration

increase in the amount of $\mathrm{Fe}(\mathrm{II})$ after $250 \mathrm{~h}$. In the system inoculated with the alkaliphilic Fe(III)-reducing community, the amount of $\mathrm{Fe}(\mathrm{II})$ increased to $\sim 4000 \mu \mathrm{mol} \mathrm{L} \mathrm{L}^{-1}$ after $\sim 1000 \mathrm{~h}$. In the system inoculated with the $\mathrm{Cr}(\mathrm{VI})$ medium community, the amount of $\mathrm{Fe}(\mathrm{II})$ increased to $\sim 1500 \mu \mathrm{mol} \mathrm{\textrm {L } ^ { - 1 }}$ after $\sim 1200 \mathrm{~h}$. In both systems, the average $\mathrm{pH}$ dropped from 9.2 to $\sim 8$ during the first $250 \mathrm{~h}$ and then remained steady, while the amount of $\mathrm{Fe}(\mathrm{II})$ increased.

\subsection{Sequencing of the Bacteria Population}

Cloning and sequencing of the bacteria from the $\mathrm{FeCr} 200$ medium produced 28 sequences from the three different genera of bacteria presented. MOTHUR analysis indicated that there were four OTUs (based on $>98 \%$ nearest neighbour similarity) which were the same as OTUs found in the original bacterial community (see Fig. 5). There were single Tissierella B and Tissierella C sequences, 19 Clostridium XI sequences and seven Alkaliphilus sequences (the representative sequences

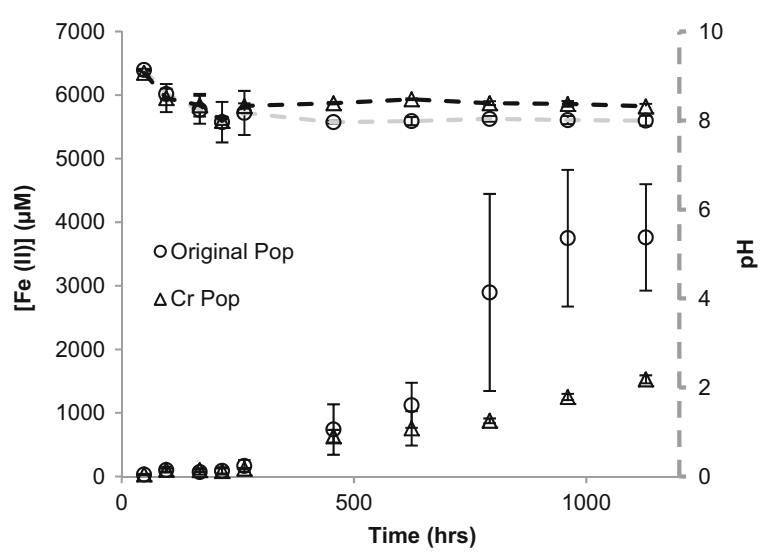

Fig. 4 Average $\mathrm{Fe}(\mathrm{II})$ concentration and $\mathrm{pH}$ for bacteria grown in aquifer sand medium. Circle denotes bacterial inoculum from the original Fe(III)-citrate medium. Triangle denotes bacterial inoculum from $\mathrm{Cr}(\mathrm{VI})$ medium. Error bars indicate one standard deviation from the mean of each OTU from this population had the GenBank numbers KF797990, KF797997, KF798001 and KF797986, respectively).

Sixty sequences were obtained from the $\mathrm{Cr}(\mathrm{VI})$ medium, and 59 were from genus Clostridium XI (representative sequence KF797963). These belonged to the same OTU as the Clostridium XI in the original bacterial community. One sequence was from genus Micrococcus (sequence KF797945, which has a $97 \%$ RDP similar score when compared to Micrococcus luteus). When this population was inoculated back into $\mathrm{Fe}(\mathrm{III})$-citrate medium, all 47 sequences were Clostridium XI (representative sequence KF798082). When it was then grown on solid phase Fe(III), all 32 sequences were Clostridium XI (representative sequence KF798143). In both cases, these sequences were part of the same OTU as the Clostridium XI in the original bacterial community.

When the alkaliphilic Fe(III)-reducing community was grown on solid phase Fe(III), 59 sequences were obtained from three different genera of bacteria. There are four different OTUs, three from the original population (5 Tissierella B sequences, 37 Tissierella $\mathrm{C}$ sequences and 2 Clostridium XI sequences) plus an OTU containing 15 Actinomycetales sequences (representative sequence KF798135).

\subsection{Analysis for of Soluble Electron-Shuttling Compounds}

To investigate whether a soluble electron shuttling compound was involved in $\mathrm{Fe}(\mathrm{III})$ reduction, the spectral properties of the spent aquifer sand medium were studied. Two inoculums were used with aquifer sand medium: the original $\mathrm{Fe}(\mathrm{III})$-reducing community and the Clostridium XI dominated, $\mathrm{Cr}(\mathrm{VI})$ medium community. Scanning the culture supernatants over a wavelength range of 300$550 \mathrm{~nm}$ revealed a large asymmetric double peak in the spent medium from the Fe(III)-reducing community, whereas there was only a very slight peak from the $\mathrm{Cr}(\mathrm{VI})$ medium community 
Fig. 5 Pie charts showing the percentage of the bacterial population assigned to each OTU from a $\mathrm{Fe}$ (III)-citrate medium. $\mathbf{b}$ Bacteria from a grown in aquifer sand medium. c Bacteria from A grown repeatedly in $\mathrm{Cr}(\mathrm{VI})$ medium. $\mathbf{d}$ Bacteria from A grown in $\mathrm{FeCr} 200$ medium. e Bacteria from $\mathrm{C}$ grown in $\mathrm{Fe}(\mathrm{III})-$ citrate medium. f Bacteria from $\mathrm{E}$ grown in aquifer sand medium
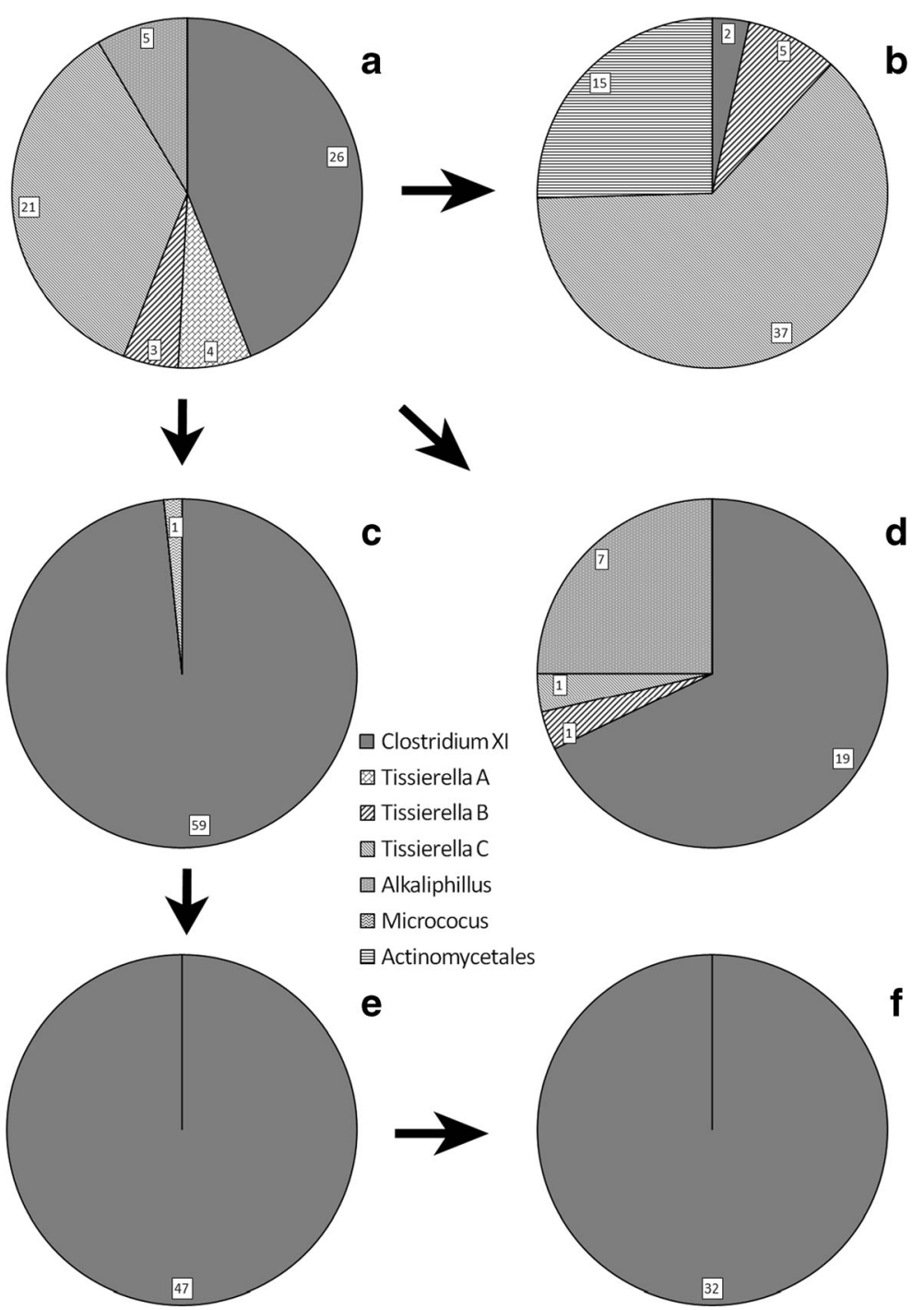

(Fig. 6a). Extraction of the extracellular compounds using an XAD-column showed a large double peak from the original Fe consortium, whereas there was a very minor peak associated with the Cr consortium (Fig. 6b). Upon excitation at $441 \mathrm{~nm}$, the emission spectra from the extracellular compound from the $\mathrm{Fe}(\mathrm{III})$-reducing community were found to be indistinguishable from those exhibited by commercially available riboflavin (Fig. 6c). Quantification of the flavin compounds revealed there to be approximately $0.11 \mu \mathrm{mol} \mathrm{L} \mathrm{L}^{-1}$ in the $\mathrm{Fe}$ (III)-reducing community supernatant and

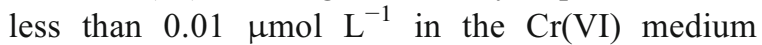
community supernatant.

\section{Discussion}

4.1 Fe(III) Reduction Supports Growth of the Bacterial Community

The alkaliphilic Fe(III)-reducing community has evolved very little since the consortium was first cultivated by Whittleston et al. (2011), despite numerous further growth cycles in Fe(III)-citrate medium. Therefore, the population of this enrichment culture is considered stable when grown in this medium. It is dominated by a Clostridium XI and a Tissierella species (Tissierella C), which together form $80 \%$ of the community (two other Tissierella and one Alkaliphilus species form the 

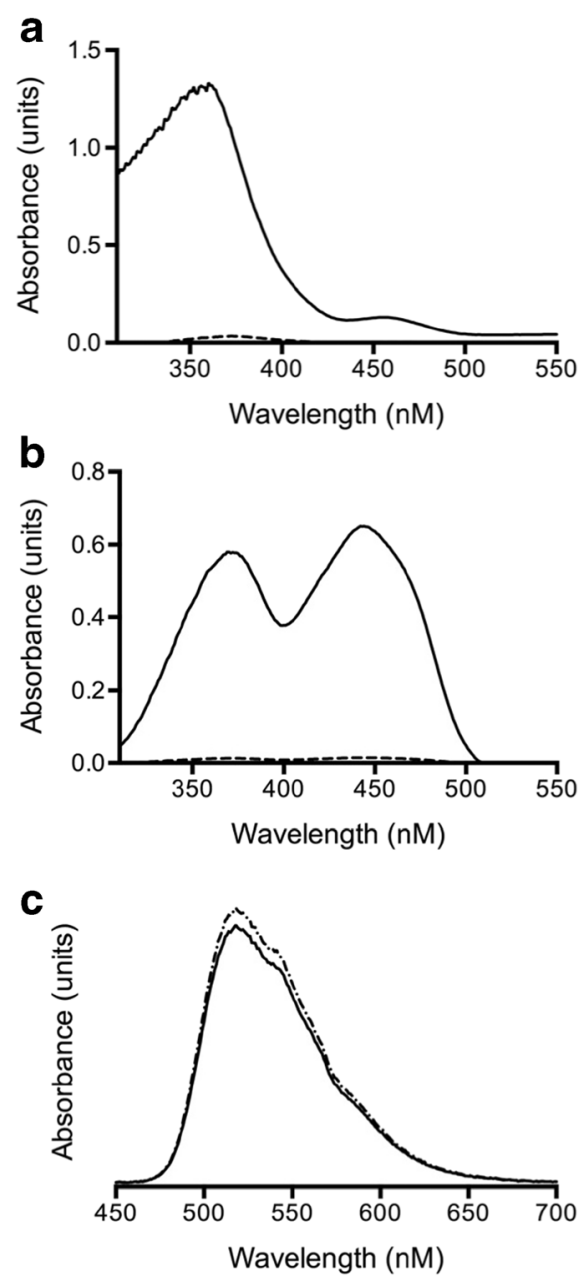

Fig. 6 Spectral properties of spent aquifer sand medium after growth of the $\mathrm{Fe}(\mathrm{III})$-reducing and $\mathrm{Cr}(\mathrm{VI})$-medium communities. UV-visible spectra after a community growth and $\mathbf{b}$ isolation of extracellular compounds (solid lines are used for Fe(III)-reducing consortium, dotted lines for the $\mathrm{Cr}(\mathrm{VI})$-medium communities). c Fluorescence spectrum of extracellular compounds isolated from $\mathrm{Fe}$ (III)-reducing community supernatant (chain-linked line) compared to that from commercial pure riboflavin (solid line). Upon excitation at $441 \mathrm{~nm}$, the emission spectra were monitored between 450 and $700 \mathrm{~nm}$

balance of the population; Fig. 5a). When cultured in $\mathrm{Fe}(\mathrm{III})$-citrate medium, growth of the bacterial community is linked to $\mathrm{Fe}(\mathrm{III})$ reduction, and therefore, it is likely that one or more species in the community is able to use $\mathrm{Fe}(\mathrm{III})$ as the electron acceptor.

This bacterial community also grew without an exogenic electron acceptor (i.e. in the basal or Nacitrate media) presumably by utilising fermentable substrates in the yeast extract. A small number of clones from the base and $\mathrm{Na}$-citrate media were sequenced for control purposes, and these showed that the main species were again Tissierella $C$ and Clostridium XI, as in the original population. Comparison of the cell numbers when the bacterial community is grown in the three media (Fig. 2) clearly shows that the absence of Fe(III) from the medium results in less growth of this community (citrate did not have a significant impact on growth). However, whilst there is more growth in $\mathrm{Fe}(\mathrm{III})$-containing medium, and this growth is coupled to its reduction to $\mathrm{Fe}(\mathrm{II})$, there is no direct evidence that the community uses $\mathrm{Fe}$ (III) as part of anaerobic respiration. Indeed, with a community of fermentative bacteria from the order Clostridiales, it is quite likely that Fe(III) reduction is being used by the cells to maintain internal redox balance during fermentative metabolism (Garnova et al. 2003; Kevbrin et al. 1998).

\subsection{Cr(VI) Puts a Selective Pressure the Bacterial Community}

Attempts to grow the alkaliphilic Fe(III)-reducing community in $\mathrm{Cr}(\mathrm{VI})$ medium were only partially successful, with no growth in some replicates and attempts to culture-on the community failing completely after 10 growth cycles. Failure to get a community that grew reliably meant that growth could not be characterised in detail, but the time taken for complete removal of $200 \mu \mathrm{mol} \mathrm{L}{ }^{-1} \mathrm{Cr}(\mathrm{VI})$ from solution was very similar to the time taken for complete $\mathrm{Cr}(\mathrm{VI})$ removal from the $\mathrm{FeCr} 200$ medium (in both cases about 25 to 30 days). Growth in $\mathrm{Cr}(\mathrm{VI})$ medium puts a strong selective pressure on the original community, and after seven growth cycles, the population was dominated by the Clostridium XI species (Fig. 5c). This indicates that this is the most $\mathrm{Cr}(\mathrm{VI})$-tolerant species in the original population; however, the fragile nature of the growth suggests that this bacterium can only just tolerate $\mathrm{Cr}(\mathrm{VI})$.

All the FeCr medium tests with initial $\mathrm{Cr}(\mathrm{VI})$ concentrations from 100 to $2000 \mu \mathrm{mol} \mathrm{L}^{-1}$ exhibited similar patterns in $\mathrm{Cr}(\mathrm{VI})$ removal, cell growth and $\mathrm{Fe}(\mathrm{III})$ reduction. $\mathrm{Cr}(\mathrm{VI})$ removal from solution started after about 20 days and was substantially complete before there was a significant change in the cell numbers. At the prevailing $\mathrm{pH}$ and $\mathrm{Cr}(\mathrm{VI})$ concentrations, the dominant aqueous $\mathrm{Cr}(\mathrm{VI})$ species is $\mathrm{CrO}_{4}{ }^{2-}$ (Richard and Bourg 1991), so sorption to cells was probably low because cell walls become increasingly negatively charged as $\mathrm{pH}$ increases (Ams et al. 2004). Also, $\mathrm{Cr}$ (VI) removal would be expected to start upon contact with the cells if the mechanism was sorption. It is therefore 
most likely that the bacterial community mediated the $\mathrm{Cr}(\mathrm{VI})$ removal from solution by a mechanism involving reductive transformation to $\mathrm{Cr}(\mathrm{III})$, which is predicted to precipitate as $\mathrm{Cr}$ (III) hydroxide at the prevailing $\mathrm{pH}$ value (Fendorf 1995) unless it is complexed by the citrate in the growth medium. Thus, $\mathrm{Cr}(\mathrm{VI})$ removal from $\mathrm{FeCr}$ medium appears to be associated with cell metabolism, but not with growth in cell numbers, probably because $\mathrm{Cr}(\mathrm{VI})$ inhibits cell growth.

Some anaerobic bacteria can reduce $\mathrm{Cr}(\mathrm{VI})$ as part of anaerobic respiration (Myers et al. 2000; Tebo and Obraztsova 1998), but frequently, it is a consequence of cellular uptake (Dhal et al. 2013). Chromate $\left(\mathrm{CrO}_{4}{ }^{2-}\right)$ is isomorphous to sulphate $\left(\mathrm{SO}_{4}{ }^{2-}\right)$ and easily crosses cell membrane of most bacteria to where it can be reduced to $\mathrm{Cr}(\mathrm{III})$ by cytoplasmic enzymes (Cervantes and Silver 1992), which is toxic as it forms stable bonds with protein and DNA in the cytoplasm (Costa 1997). Thus, the period when there was $\mathrm{Cr}(\mathrm{VI})$ reduction without apparent increase in cell numbers may be a period of fermentative cell growth balanced by cell death due to chromium toxicity. On the other hand, it has been shown that the community can grow fermentatively in the base medium and can reduce $\mathrm{Fe}$ (III) when it is present in the medium, probably as means of maintaining the fermentation redox balance. As $\mathrm{Cr}(\mathrm{VI})$ is readily reduced to $\mathrm{Cr}(\mathrm{III})$ by reoxidation of $\mathrm{Fe}(\mathrm{II})$ to $\mathrm{Fe}(\mathrm{III})$ (Richard and Bourg 1991), $\mathrm{Cr}(\mathrm{VI})$ reduction in $\mathrm{FeCr}$ medium may be the consequence of the onset of iron reduction (Fe(II) will only accumulate in the medium once all $\mathrm{Cr}(\mathrm{VI})$ has been reduced). The accumulation of $\mathrm{Fe}$ (II) in the $\mathrm{FeCr}$ medium immediately after exhaustion of Cr(VI) may seem to be indicative of the latter mechanism. However, this indirect mechanism involving $\mathrm{Fe}(\mathrm{II}) / \mathrm{Fe}$ (III) cycling cannot explain $\mathrm{Cr}(\mathrm{VI})$ reduction in $\mathrm{Cr}(\mathrm{VI})$ medium, where there was no source of $\mathrm{Fe}(\mathrm{III})$. Equally, the similar time taken to remove $200 \mu \mathrm{mol} \mathrm{L}^{-1} \mathrm{Cr}(\mathrm{VI})$ from the $\mathrm{Cr}(\mathrm{VI})$ and $\mathrm{FeCr} 200$ media seems indicative of similar $\mathrm{Cr}(\mathrm{VI})$ reduction mechanisms in the two systems, suggesting either a cellular uptake mechanism or possibly direct $\mathrm{Cr}(\mathrm{VI})$ reduction as means of maintaining the fermentation redox balance (i.e. a similar mechanism to $\mathrm{Fe}$ (III) reduction). However, the data presented here cannot determine which is more likely mechanism of $\mathrm{Cr}(\mathrm{VI})$ reduction.

The final cell numbers after complete Fe(III) reduction were of similar order of magnitude in the $\mathrm{FeCr}$ and $\mathrm{Fe}(\mathrm{III})$-citrate media. However, in the $\mathrm{FeCr} 200$ medium, the proportion of the population that were Clostridium $X I$ and Alkaliphilus species increased, while the proportion that were Tissierella species was much reduced compared with the original population (the relative abundances of Clostridium XI and Alkaliphilus were similar in the two media). This change in community composition after a single growth cycle suggests that the Tissierella species have very low tolerance for $\mathrm{Cr}(\mathrm{VI})$.

The FeCr medium tests with very high initial $\mathrm{Cr}(\mathrm{VI})$ concentrations (4500 and $8500 \mu \mathrm{mol} \mathrm{L}{ }^{-1}$ ) behaved differently from those containing lower concentrations. In the $\mathrm{FeCr} 4500$ medium, the removal of $\mathrm{Cr}(\mathrm{VI})$ from solution started after about 32 days and was only $60 \%$ complete after 56 days, yet cell numbers started to increase after 39 days. In the FeCr8500 medium, there was very little change in the $\mathrm{Cr}(\mathrm{VI})$ concentration (it decreased by $\sim 10 \%$ over the test), yet cell numbers started to increase after $\sim 60$ days. The final microbial population in the FeCr8500 medium consisted of Brevibacterium and Actinomycetales bacteria (see Supplementary Information Fig. 1). These hardier species were presumably a very small component of the initial population that are not able to compete effectively with the main population when grown in $\mathrm{Fe}(\mathrm{III})$-citrate medium but were able to grow fermentatively using yeast extract when there was extreme $\mathrm{Cr}(\mathrm{VI})$ stress, because these conditions were not conductive to growth of the other species.

\subsection{A Change in the State of Fe(III) Source Puts a Selective Pressure the Bacterial Community}

When the alkaliphillic Fe(III)-reducing community was cultured in aquifer sand medium, Fe(III) reduction to $\mathrm{Fe}(\mathrm{II})$ became apparent after about 10 days, which is significantly slower than was observed with Fe(III)citrate medium (where Fe(III) reduction was apparent after 4 days). The difference is probably associated with the availability of $\mathrm{Fe}$ (III) to the bacteria. In the aquifer sand, Fe(III) is present as Fe(III) oxyhydroxides in fine particles and grain coatings, which is probably less accessible to bacteria than an aqueous Fe(III)-citrate complex (in the absence of complexing ligands, such as citrate, $\mathrm{Fe}(\mathrm{III})$ is very sparingly soluble at $\mathrm{pH}$ values above pH8: Langmuir 1997). Growth in aquifer sand medium led to an increased abundance of Tissierella $C$ species (from $\sim 1 / 3$ to $>2 / 3$ of sequences). Growth of the community was also associated with the release of a riboflavin-like molecule into the aquifer sand medium. It has previously been shown that growth of the alkaliphilic $\mathrm{Fe}$ (III)-reducing community in Fe(III)- 
citrate medium results in the release of riboflavin contemporaneously with $\mathrm{Fe}$ (III) reduction and that the Tissierella $C$ sp. can reduce Fe(III) remote from the cells when grown anaerobically on agar-Fe(III)-citrate medium plates (Fuller et al. 2014). Thus, it seems likely that the Tissierella $C$ species can release riboflavin as an electron shuttling compound to facilitate extracellular electron transfer, and this may give it a competitive advantage when grown of aquifer sand medium.

Growth of the Clostridium XI dominated, $\mathrm{Cr}(\mathrm{VI})$ medium community in aquifer sand medium did not result in any further change in the community composition, probably because community diversity was lost during repeated growth in $\mathrm{Cr}(\mathrm{VI})$ medium (populations $\mathrm{C}, \mathrm{E}$ and $\mathrm{F}$ in Fig. 5). Also, while the increase in Fe(II) concentration started after a similar lag-time with the two populations, the amount of $\mathrm{Fe}(\mathrm{II})$ produced by the $\mathrm{Cr}(\mathrm{VI})$-medium community after 50 days was about one third that produced by the alkaliphillic Fe(III)-reducing community (Fig. 4). Thus, the rate at which the Cr(VI)medium community could reduce that $\mathrm{Fe}(\mathrm{III})$ is significantly slower than the Tissierella $C$-dominated community. No significant release of riboflavin was associated with growth of the $\mathrm{Cr}(\mathrm{VI})$-medium community; thus, the absence of an electron shuttling compound may explain the slower rate of $\mathrm{Fe}(\mathrm{III})$ reduction. However, the $\mathrm{Cr}(\mathrm{VI})$-medium community can clearly reduce $\mathrm{Fe}(\mathrm{III})$ when grown in aquifer sand medium, and thus, the Clostridium XI specie must possess a mechanism from transferring electrons external electron acceptors. Given the lower rate of Fe(III) reduction and the absence of an electron shuttling compound, it is speculated that $\mathrm{Fe}(\mathrm{III})$ reduction might involve direct contact between the cell and the iron bearing solid phase.

\subsection{Implications for Bioremediation Processes at COPR Impacted Sites}

This paper clearly shows that bioremediation has great potential for the treatment of highly alkaline COPR impacted sites. Leachate from the historical COPR site from which the bacteria were cultivated has a $\mathrm{Cr}(\mathrm{VI})$ concentration of $1000 \mu \mathrm{mol} \mathrm{L}{ }^{-1}$ within the waste and $200 \mu \mathrm{mol} \mathrm{L}{ }^{-1}$ within the drainage ditch adjacent to the site (Stewart et al. 2010). This study shows that bacteria from the same site are able to grow and reduce chromate in solutions containing up to $2000 \mu \mathrm{mol} \mathrm{L}{ }^{-1} \mathrm{Cr}(\mathrm{VI})$ provided a source of $\mathrm{Fe}(\mathrm{III})$ is present. This exceeds the maximum leachate concentration reported for any
COPR disposal site thus far. In most microcosms, the $\mathrm{pH}$ buffered downwards to around 8.5 before the exponential phase of growth indicating that the bacteria in this study are most comfortable at lower $\mathrm{pH}$. This is interesting as other work has found that buffering the $\mathrm{pH}$ down to $\sim 9$ results in more robust $\mathrm{Fe}(\mathrm{III})$ reduction in COPR-contaminated soils (Whittleston et al. 2013).

The $\mathrm{pH}$ of COPR leachate is high in comparison with the $\mathrm{pH}$ range used in this study, but it is quickly buffered by interactions with soil (Whittleston 2011). This study suggests that in bioremediation (i.e. by addition of labile organic matter to soils) should be successful in areas where this has occurred. Addition of acid or bicarbonate to increase $\mathrm{pH}$ buffering may further increase the likelihood of success. Indeed, where sufficient labile organic matter is naturally present, lowering the soil $\mathrm{pH}$ to $\leq 9$ may be all that is required to initiate bioreduction (Whittleston et al. 2013).

Few bacterial species have been reported that can use $\mathrm{Cr}(\mathrm{VI})$ as an electron acceptor to support cell growth. Thus at a contaminated site, iron-reducing microorganisms are likely to outnumber $\mathrm{Cr}(\mathrm{VI})$ reducers, as ironreducing microorganisms are numerous and widespread in nature (Lovley 2006). This is supported by the fact that only Clostridium XI in this study could grow weakly with $\mathrm{Cr}(\mathrm{VI})$ as an electron acceptor, and it grew far more robustly with $\mathrm{Fe}(\mathrm{III})$. Therefore, the accumulation of $\mathrm{Fe}(\mathrm{II})$ in soils and subsequent abiotic reduction of $\mathrm{Cr}(\mathrm{VI})$ by solid associated $\mathrm{Fe}(\mathrm{II})$ is probably the most important mechanism of $\mathrm{Cr}(\mathrm{VI})$ reduction at COPR sites.

However, it is also clear that several of the species present (e.g. the Tissierella $C$ sp.) in the Fe(III)-reducing enrichment culture have a low tolerance for $\mathrm{Cr}(\mathrm{VI})$ despite being recovered from immediately beneath a COPR waste tip. This may indicate that micro-habitats are important on site, with species such as Tissierella restricted to local environments where $\mathrm{Cr}(\mathrm{VI})$ concentration is low. Indeed, the soluble electron shuttling compound produced by Tissierella $C$ may be important to the creation of micro-habitats as it can facilitate $\mathrm{Fe}(\mathrm{III})$-reduction remote from the cells, producing $\mathrm{Fe}(\mathrm{II})$ in the soils, which can indirectly remove $\mathrm{Cr}(\mathrm{VI})$ from the local environment around the cells.

\section{Conclusions}

Growth and community structure of the consortium of alkaliphilic Fe(III)-reducing bacteria were significantly 
affected by changes in growth conditions. When $\mathrm{Cr}(\mathrm{VI})$ was added to the $\mathrm{Fe}$ (III)-citrate growth medium, the Tissierella $\mathrm{sp}$. that were present in the original culture reduced in abundance and died out completely when the community was grown on $\mathrm{Cr}(\mathrm{VI})$ medium. Of the species present in the original community, the Clostridium XI sp. was most tolerant of higher $\mathrm{Cr}(\mathrm{VI})$ concentrations, but even this species only grew weakly in a $\mathrm{Cr}(\mathrm{VI})$ medium, dying out after only 10 growth cycles. Conversely, when solid phase $\mathrm{Fe}$ (III) oxyhydroxides were provided in the growth medium, the Tissierella $\mathrm{C}$ sp. increased in abundance relative to other bacteria in the initial community. This was possibly due to the Tissierella $\mathrm{C}$ sp. producing riboflavin as an extracellular electron shuttling compound allowing more efficient reduction of the solid Fe(III) phases present. The indigenous bacteria recovered from soils beneath COPR waste are shown to adopt several different strategies for survival in presence of an influx alkaline $\mathrm{Cr}(\mathrm{VI})$-containing water; however, strategies involving $\mathrm{Fe}(\mathrm{III})-$ reduction produced more robust and reproducible growth. Stimulation of bacterial growth in the soils adjunct to COPR sites is therefore likely to create conditions where $\mathrm{Fe}$ (II) accumulation in those soils acts as an in situ barrier that reduces $\mathrm{Cr}(\mathrm{VI})$ mobility and toxicity.

Acknowledgments SJF would like to acknowledge his funding from the John Henry Garner Scholarship at the University of Leeds. WD acknowledges support from an EPSRC Doctoral Training Award. The authors would like to thank Dr. Robert Whittleston for the initial cultivation of the bacteria population, Lesley Neve and Mark Whittaker for help with the XRF and XRD analysis respectively, and Dr. Phil Studds and Mark Bell at Ramboll UK for enabling fieldwork at the COPR-contaminated site.

Open Access This article is distributed under the terms of the Creative Commons Attribution 4.0 International License (http:// creativecommons.org/licenses/by/4.0/), which permits unrestricted use, distribution, and reproduction in any medium, provided you give appropriate credit to the original author(s) and the source, provide a link to the Creative Commons license, and indicate if changes were made.

\section{References}

Abdelouas, A., Lu, Y., Lutze, W., \& Nuttall, H. E. (1998). Reduction of U(VI) to U(IV) by indigenous bacteria in contaminated ground water. Journal of Contaminant Hydrology, 35(1-3), 217-233.

Ams, D. A., Fein, J. B., Dong, H., \& Maurice, P. A. (2004). Experimental measurements of the adsorption of Bacillus subtilis and Pseudomonas mendocina onto Feoxyhydroxide coated and uncoated quartz grains. Geomicrobiology Journal, 21, 511-519.

Anderson, R. T., Vrionis, H. A., Ortiz-Bernad, I., Resch, C. T., Long, P. E., Dayvault, R., et al. (2003). Stimulating the in situ activity of Geobacter species to remove uranium from the groundwater of a uranium-contaminated aquifer. Applied and Environmental Microbiology, 69(10), 5884-5891.

Ashelford, K. E., Chuzhanova, N. A., Fry, J. C., Jones, A. J., \& Weightman, A. J. (2006). New screening software shows that most recent large 16S rRNA gene clone libraries contain chimeras. Applied and Environmental Microbiology, 72(9), 5734-5741.

Bae, S., \& Lee, W. (2013). Biotransformation of lepidocrocite in the presence of quinones and flavins. Geochimica et Cosmochimica Acta, 114, 144-155.

Barker, H. A. (1981). Amino acid degradation by anaerobic bacteria. Annual Review of Biochemistry, 50(1), 23-40.

Bruce, R. A., Achenbach, L. A., \& Coates, J. D. (1999). Reduction of (per) chlorate by a novel organism isolated from paper mill waste. Environmental Microbiology, 1(4), 319-329.

Burke, I. T., Boothman, C., Lloyd, J. R., Livens, F. R., Charnock, J. M., McBeth, J. M., et al. (2006). Reoxidation behavior of technetium, iron, and sulfur in estuarine sediments. Environmental Science and Technology, 40(11), 3529-3535.

Burke, I. T., Peacock, C. L., Lockwood, C. L., Stewart, D. I., Mortimer, R. J. G., Ward, M. B., et al. (2013). Behavior of aluminum, arsenic, and vanadium during the neutralization of red mud leachate by $\mathrm{HCl}$, gypsum, or seawater. Environmental Science and Technology, 47(12), 6527-6535.

Carpentier, W., De Smet, L., Van Beeumen, J., \& Brigé, A. (2005). Respiration and growth of Shewanella oneidensis MR-1 using vanadate as the sole electron acceptor. Journal of Bacteriology, 187(10), 3293-3301.

Cervantes, C., \& Silver, S. (1992). Plasmid chromate resistance and chromate reduction. Plasmid, 27(1), 65-71.

Charlet, L., Scheinost, A. C., Tournassat, C., Greneche, J. M., Géhin, A., Fernández-Martínez, A., et al. (2007). Electron transfer at the mineral/water interface: selenium reduction by ferrous iron sorbed on clay. Geochimica et Cosmochimica Acta, 71(23), 5731-5749.

Claesson, M. J., O’Sullivan, O., Wang, Q., Nikkila, J., Marches, J. R., Smidt, H., et al. (2009). Comparative analysis of pyrosequencing and a phylogenetic microarray for exploring microbial community structures in the human distal intestine. PLoS ONE, 4(8), e6669.

Costa, M. (1997). Toxicity and carcinogenicity of Cr(VI) in animal models and humans. Critical Reviews in Toxicology, 27(5), 431-442.

Daulton, T. L., Little, B. J., Jones-Meehan, J., Blom, D. A., \& Allard, L. F. (2007). Microbial reduction of chromium from the hexavalent to divalent state. Geochimica et Cosmochimica Acta, 71(3), 556-565.

Deakin, D., West, L. J., Stewart, D. I., \& Yardley, B. W. D. (2001). Leaching behaviour of a chromium smelter waste heap. Waste Management, 21(3), 265-270.

Dhal, B., Thatoi, H. N., Das, N. N., \& Pandey, B. D. (2013). Chemical and microbial remediation of hexavalent chromium from contaminated soil and mining/metallurgical solid waste: a review. Journal of Hazardous Materials, 250-251, 272-291. 
Dobbin, P. S., Carter, J. P., Garcia-Salamanca San Juan, C., von Hobe, M., Powell, A. K., \& Richardson, D. J. (1999). Dissimilatory $\mathrm{Fe}(\mathrm{III})$ reduction by Clostridium beijerinckii isolated from freshwater sediment using Fe(III) maltol enrichment. FEMS Microbiol Lett, 176(1), 131-138.

Eden, P. A., Schmidt, T. M., Blakemore, R. P., \& Pace, N. R. (1991). Phylogenetic analysis of aquaspirillum magnetotacticum using polymerase chain reaction-amplified 16S rRNA-specific DNA. International Journal of Systematic Bacteriology, 41(2), 324-325.

Fendorf, S. E. (1995). Surface reactions of chromium in soils and waters. Geoderma, 67(1-2), 55-71.

Fuller, S.J. (2013). Sustainable engineering treatment for highly alkaline chromate contaminated groundwater. (University of Leeds).

Fuller S. J., McMillan D. G. G., Renz M. B., Schmidt M., Burke I. T. \& Stewart D. I. (2014). Extracellular electron transport mediated $\mathrm{Fe}(\mathrm{III})$ reduction by a community of alkaliphilic bacteria that use flavins as electron shuttles. Applied and Environmental Microbiology, 80(1), 128-137.

Garnova, E. S., Zhilina, T. N., Tourova, T. P., \& Lysenko, A. M. (2003). Anoxynatronum sibiricum gen.nov., sp.nov alkaliphilic saccharolytic anaerobe from cellulolytic community of Nizhnee Beloe (Transbaikal region). Extremophiles, 7(3), 213-220.

Glasauer, S., Langley, S., Boyanov, M., Lai, B., Kemner, K., \& Beveridge, T. J. (2007). Mixed-valence cytoplasmic iron granules are linked to anaerobic respiration. Applied and Environmental Microbiology, 73(3), 993-996.

Gorby, Y. A., Yanina, S., McLean, J. S., Rosso, K. M., Moyles, D., Dohnalkova, A., et al. (2006). Electrically conductive bacterial nanowires produced by Shewanella oneidensis strain MR-1 and other microorganisms. Proceedings of the National Academy of Sciences, 103(30), 11358-11363.

Gorlenko, V., Tsapin, A., Namsaraev, Z., Teal, T., Tourova, T., Engler, D., et al. (2004). Anaerobranca californiensis sp nov., an anaerobic, alkalithermophilic, fermentative bacterium isolated from a hot spring on Mono Lake. International Journal of Systematic and Evolutionary Microbiology, 54, 739-743.

Gottschalk, G. (1986). Bacterial metabolism (Spinger series in microbiology 2nd ed.). New York: Springer-Verlag.

Harish, R., Samuel, J., Mishra, R., Chandrasekaran, N., \& Mukherjee, A. (2012). Bio-reduction of $\mathrm{Cr}(\mathrm{VI})$ by exopolysaccharides (EPS) from indigenous bacterial species of Sukinda chromite mine, India. Biodegradation, 23(4), 487-496.

Higgins, T. E., Halloran, A. R., Dobbins, M. E., \& Pittignano, A. J. (1998). In situ reduction of hexavalent chromium in alkaline soils enriched with chromite ore processing residue. Journal of the Air and Waste Management Association, 48(11), 11001106.

Jankowski, J., Ward, C. R., French, D., \& Groves, S. (2006). Mobility of trace elements from selected Australian fly ashes and its potential impact on aquatic ecosystems. Fuel, 85(2), 243-256.

Kevbrin, V. V., Zhilina, T. N., Rainey, F. A., \& Zavarzin, G. A. (1998). Tindallia magadii gen. nov., sp. nov.: an alkaliphilic anaerobic ammonifier from soda lake deposits. Current Microbiology, 37(2), 94-100.

Kim, B.H.,\& Gadd, G.M. (2008). Bacterial physiology and metabolism (Cambridge University Press).
Lane, D. J. (1991). 16S/23S rRNA sequencing. In E. Stackebrandt \& M. Goodfellow (Eds.), Nucleic acid techniques in bacterial systematics. Chichester: Wiley.

Langmuir, D. (1997). Aqueous environmental geochemistry (Prentice Hall).

Liermann, L. J., Hausrath, E. M., Anbar, A. D., \& Brantley, S. L. (2007). Assimilatory and dissimilatory processes of microorganisms affecting metals in the environment. Journal of Analytical Atomic Spectrometry, 22(8), 867-877.

Liu, C., Gorby, Y. A., Zachara, J. M., Fredrickson, J. K., \& Brown, C. F. (2002). Reduction kinetics of Fe(III), Co (III), U (VI), $\mathrm{Cr}$ (VI), and Tc (VII) in cultures of dissimilatory metalreducing bacteria. Biotechnology and Bioengineering, $80(6), 637-649$.

Lloyd, J. R., \& Lovley, D. R. (2001). Microbial detoxification of metals and radionuclides. Current Opinion in Biotechnology, 12(3), 248-253.

Lloyd, J. R., Sole, V. A., Van Praagh, C. V. G., \& Lovley, D. R. (2000). Direct and Fe(II)-mediated reduction of technetium by $\mathrm{Fe}(\mathrm{III})-$ reducing bacteria. Applied and Environmental Microbiology, 66(9), 3743-3749.

Lovley, D. R. (1993). Dissimilatory metal reduction. Annual Review of Microbiology, 47(1), 263-290.

Lovley, D. R. (2001). Anaerobes to the rescue. Science, 293(5534), 1444-1446.

Lovley, D R (2006). Dissimilatory Fe(III) and Mn(IV) reducing Prokaryotes. In: The Prokaryotes: A Handbook on the Biology of Bacteria. Vol. 2: Ecophysiology and Biochemistry Springer.

Lovley, D. R. (2008). Extracellular electron transfer: wires, capacitors, iron lungs, and more. Geobiology, 6(3), 225-231.

Lovley, D. R., \& Phillips, E. J. P. (1986). Availability of ferric iron for microbial reduction in bottom sediments of the freshwater tidal potomac river. Applied and Environmental Microbiology, 52(4), 751-757.

Lovley, D. R., \& Phillips, E. J. P. (1994). Reduction of chromate by Desulfovibro-Vulgaris and its C (3) cytochrome. Applied and Environmental Microbiology, 60(2), 726-728.

Lovley, D. R., Fraga, J. L., Blunt-Harris, E. L., Hayes, L. A., Phillips, E. J. P., \& Coates, J. D. (1998). Humic substances as a mediator for microbially catalyzed metal reduction. Acta Hydrochimica et Hydrobiologica, 26(3), 152-157.

Madigan, M.T., Martinko, J.M., Parker, J. (2003). Brock biology of microorganisms (Prentice Hall/Pearson Education).

Mayes, W. M., \& Younger, P. L. (2006). Buffering of alkaline steel slag leachate across a natural wetland. Environmental Science \& Technology, 40(4), 1237-1243.

Mayes, W. M., Younger, P. L., \& Aumônier, J. (2008). Hydrogeochemistry of alkaline steel slag leachates in the UK. Water, Air, and Soil Pollution, 195(1-4), 35-50.

McMillan, D. G., Keis, S., Berney, M., \& Cook, G. M. (2009). Nonfermentative thermoalkaliphilic growth is restricted to alkaline environments. Applied and Environmental Microbiology, 75(24), 7649-7654.

McMillan, D. G., Velasquez, I., Nunn, B. L., Goodlett, D. R., Hunter, K. A., Lamont, I., et al. (2010). Acquisition of iron by alkaliphilic bacillus species. Applied and Environmental Microbiology, 76(20), 6955-6961.

Mitchell, P. (1961). Coupling of phosphorylation to electron and hydrogen transfer by a chemi-osmotic type of mechanism. Nature, 191(4784), 144-148. 
Myers, C. R., Carstens, B. P., Antholine, W. E., \& Myers, J. M. (2000). Chromium (VI) reductase activity is associated with the cytoplasmic membrane of anaerobically grown Shewanella putrefaciens MR-1. Journal of Applied Microbiology, 88(1), 98-106.

NABIR (2003). Bioremediation of metals and radionuclides: what it is and how it works. A NABIR primer (2nd edn.: NABIR primer prepared for US Department of Energy), p.78.

Nelson, D.L. \& Cox, M.M. (2013). Lehninger Principles of Biochemistry (6th (International) edn.: MacMillan).

O’Loughlin, E. J., Gorski, C. A., Scherer, M. M., Boyanov, M. I., \& Kemner, K. M. (2010). Effects of oxyanions, natural organic matter, and bacterial cell numbers on the bioreduction of Lepidocrocite $(\gamma-\mathrm{FeOOH})$ and the formation of secondary mineralization products. Environmental Science \& Technology, 44(12), 4570-4576.

Okamoto, A., Saito, K., Inoue, K., Nealson, K. H., Hashimoto, K., \& Nakamura, R. (2014). Uptake of self-secreted flavins as bound cofactors for extracellular electron transfer in Geobacter species. Energy \& Environmental Science, 7(4), 1357-1361.

Otto, M. K., Jayaram, M., Hamilton, R. M., \& Delbruck, M. (1981). Replacement of riboflavin by an analogue in the blue-light photoreceptor of Phycomyces. Proceedings of the National academy of Sciences of the United States of America, 78(1), 266-269.

Rey, S. \& Reggiani, G. M. (2005). Molybdate and non-molybdate options for closed systems - Part II. AWT annual convention (Palm Springs: Cooling Water Subcommittee of the AWT Technical Committee.

Richard, F. C., \& Bourg, A. C. M. (1991). Aqueous geochemistry of chromium: a review. Water Research, 25(7), 807-816.

Roh, Y., Chon, C.-M., \& Moon, J.-W. (2007). Metal reduction and biomineralization by an alkaliphilic metal-reducing bacterium, Alkaliphilus metalliredigens. Geosciences Journal, 11(4), 415-423.

Schloss, P. D., Westcott, S. L., Ryabin, T., Hall, J. R., Hartmann, M., Hollister, E. B., et al. (2009). Introducing mothur: open-source, platform-independent, community-supported software for describing and comparing microbial communities. Applied and Environmental Microbiology, 75(23), 7537-7541.

Schmitz, R. A., Daniel, R., Deppenmeier, U., \& Gottschalk, G. (2006). The anaerobic way of life. In M. Dworkin et al. (Eds.), The Prokaryotes: a handbook on the biology of bacteria (3rd ed., Vol. 2, pp. 86-101). New York: Springer.

Shen, H., \& Wang, Y.-T. (1993). Characterization of enzymatic reduction of hexavalentchromium by escherichia coli ATCC 33456. Applied and Environmental Microbiology, 59(11), 3771-3777.

Shi, L., Chen, B., Wang, Z., Elias, D. A., Mayer, M. U., Gorby, Y. A., et al. (2006). Isolation of a high-affinity functional protein complex between OmcA and MtrC: two outer membrane decaheme c-type cytochromes of Shewanella oneidensis MR-1. Journal of Bacteriology, 188(13), 4705-4714.

Shukor, M. Y., Ahmad, S. A., Nadzir, M. M. M., Abdullah, M. P., Shamaan, N. A., \& Syed, M. A. (2010). Molybdate reduction by Pseudomonas sp strain DRY2. Journal of Applied Microbiology, 108(6), 2050-2058.

Stewart, D. I., Cousens, T. W., \& Charles-Cruz, C. A. (2006). The interpretation of CPT data from hydraulically placed PFA. Engineering Geology, 85(1-2), 184-196.
Stewart, D. I., Burke, I. T., Hughes-Berry, D. V., \& Whittleston, R. A. (2010). Microbially mediated chromate reduction in soil contaminated by highly alkaline leachate from chromium containing waste. Ecological Engineering, 36(2), 211-221.

Tebo, B. M., \& Obraztsova, A. Y. (1998). Sulfate-reducing bacterium grows with $\mathrm{Cr}$ (VI), U (VI), Mn (IV), and Fe (III) as electron acceptors. FEMS Microbiology Letters, 162(1), 193-198.

USEPA (1992). SW-846 Manual: Method 7196a. Chromium hexavalent (colorimetric).

Veeramani, H., Alessi, D. S., Suvorova, E. I., LezamaPacheco, J. S., Stubbs, J. E., Sharp, J. O., et al. (2011). Products of abiotic U(VI) reduction by biogenic magnetite and vivianite. Geochimica et Cosmochimica Acta, 75(9), 2512-2528.

von Canstein, H., Ogawa, J., Shimizu, S., \& Lloyd, J. R. (2008). Secretion of Flavins by Shewanella species and their role in extracellular electron transfer. Applied and Environmental Microbiology, 74(3), 615-623.

Wang, Y.-T., \& Shen, H. (1997). Modelling Cr (VI) reduction by pure bacterial cultures. Water Research, 31(4), 727-732.

Wang, Q., Garrity, G. M., Tiedje, J. M., \& Cole, J. R. (2007). Naïve Bayesian classifier for rapid assignment of rRNA sequences into the new bacterial taxonomy. Applied and Environmental Microbiology, 73(16), 5261-5267.

Weber, K. A., Picardal, F. W., \& Roden, E. E. (2001). Microbially catalyzed nitrate-dependent oxidation of biogenic solidphase Fe(II) compounds. Environmental Science \& Technology, 35(8), 1644-1650.

Weisburg, W. G., Barns, S. M., Pelletier, D. A., \& Lane, D. J. (1991). 16S ribosomal DNA amplification for phylogenetic study. Journal of Bacteriology, 173(2), 697-703.

White, A. F., \& Peterson, M. L. (1996). Reduction of aqueous transition metal species on the surfaces of Fe(II) -containing oxides. Geochimica et Cosmochimica Acta, 60(20), 37993814.

White, G.F., Shi, Z., Shi, L., Wang, Z., Dohnalkova, A.C., Marshall, M.J., et al. (2013). Rapid electron exchange between surface-exposed bacterial cytochromes and $\mathrm{Fe}$ (III) minerals. Proceedings of the National Academy of Sciences of the United States of America.

Whittleston, R. A (2011). Bioremediation of chromate in alkaline sediment-water systems. (PhD thesis, University of Leeds.).

Whittleston, R. A., Stewart, D. I., Mortimer, R. J. G., Tilt, Z. C., Brown, A. P., Geraki, K., et al. (2011). Chromate reduction in $\mathrm{Fe}(\mathrm{II})$-containing soil affected by hyperalkaline leachate from chromite ore processing residue. Journal of Hazardous Materials, 194, 15-23.

Whittleston, R. A., Stewart, D. I., Mortimer, R. J. G., \& Burke, I. T. (2013). Enhancing microbial iron reduction in hyperalkaline, chromium contaminated sediments by $\mathrm{pH}$ amendment. Applied Geochemistry, 28, 135-144.

Zavarzina, D. G., Kolganova, T. V., Boulygina, E. S., Kostrikina, N. A., Tourova, T. P., \& Zavarzin, G. A. (2006). Geoalkalibacter ferrihydriticus gen. nov. sp. nov., the first alkaliphilic representative of the family Geobacteraceae, isolated from a soda lake. Microbiology, 75(6), 673-682.

Zwietering, M. H., Jongenburger, I., Rombouts, F. M., \& VAN'T Riet, K. (1990). Modeling of the bacterial growth curve. Applied and Environmental Microbiology, 56(6), 18751881. 